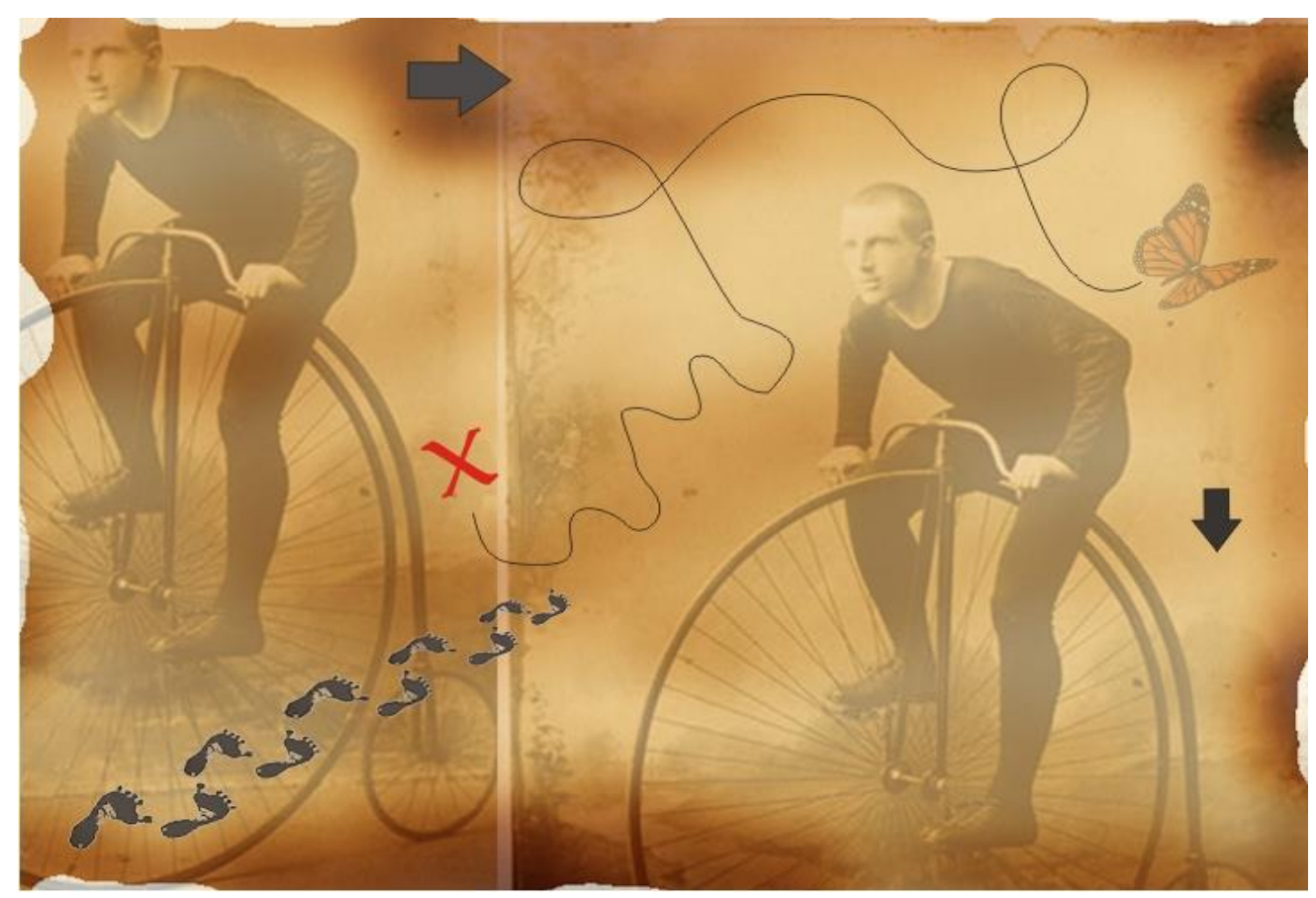

Karol Penido

\title{
Coisas de príncipes e sapos...
}

\section{Juliana Leal}

Doutoranda em Literatura Comparada, FALE/UFMG, e professora de Língua Espanhola. Mestre em Estudos Literários e professora de Língua Portuguesa, PBH.

Em sua infância, desnudar seus pés e voltar para casa com o corpo vestido de pó de asfalto e poeira e com a alma cheinha de um cansaço feliz que só os bem pequenos sabem suportar era coisa habitual.

Talvez por acordar sentindo inveja desse si próprio, por vezes presente em suas recordações, tenha se decidido. E, com o olhar muito mais alerta do que provavelmente levaria quando roçava, passo a passo, a dureza do chão de seu passado, caminhava, altivo, sob os olhares incomodados dos que com 0 dele cruzavam. Olhares que, vacilando em se decidirem pela sanidade, garantida pela camisa social, ou a demência, pelos pés pornograficamente desnudos, ainda se voltavam, de costas, para se certificarem de que a cena, de fato, não se adequava ao personagem, tampouco à ocasião.

O segundo, por insistir em apagar, a cada gole, cada um de seus sonhos (de adulto, de menino, de humano???), usava 
sapatos. Do tipo social. E, com pouca habilidade, confessada por olhos que só miravam o chão, tentava ocultar em suas mãos a razão líquida que tornava seus pés muito menos convictos do que os outros que por ali passaram. Mas que, muito provavelmente, o ajudavam a manter seus pés (e talvez sua vida) dentro de sapatos de couro.

Mas havia outro... cujos pés, ainda sem uma forma visível, e com um olhar, de igual modo, ainda sem brilho e cor, percorriam (descalços??? calçados???) um caminho absurdamente perigoso. Feito de desejo e cicatriz.

Qual deles seria, de verdade, um príncipe? Porque sapos... Não! Sapos não poderiam ser, porque esses já fixaram residência, há muito, em um sem-fim de gargantas. 